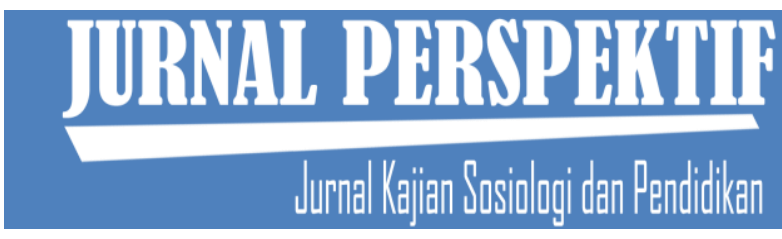

Jurnal Perspektif: Jurnal Kajian Sosiologi dan Pendidikan Vol. 3 No. 4 Tahun 2020

http://perspektif.ppj.unp.ac.id

Email: perspektif@ppj.unp.ac.id

ISSN: 2622-1748 (Online), 2684-902X (Print)

DOI: http://dx.doi.org/10.24036/perspektif.v3i4.345

Implementasi Perda Kota Padang Nomor 5 Tahun 2018 Tentang Pencegahan dan Peningkatan Kualitas Perumahan Kumuh dan Permukiman Kumuh Di Kecamatan Koto Tangah

\author{
Zilqistiyah Lubis ${ }^{1}$, Hasbullah Malau ${ }^{2}$ \\ 1,2Universitas Negeri Padang \\ Email: zilqistiyah1@gmail.com, hasbullahmalau@ gmail.com
}

\begin{abstract}
Abstrak
Pencegahan dan peningkatan kualitas kawasan kumuh merupakan kebijakan penting untuk mencegah tumbuh dan berkembangnya perumahan kumuh dan permukiman kumuh serta mewujudkan kawasan yang layak huni dan berklanjutan. Bahkan di Kecamatan Koto Tangah, perumahan dan permukiman kumuh terus tumbuh dan berkembang, yang semula hanya seluas 11,5 ha dan tersebar di 2 kecamatan kemudian bermunculan dan mengembangkan perumahan baru dan permukiman kumuh seluas 33,5 ha dan menyebar di 4 kelurahan di Kecamatan Koto Tangah. Penelitian ini menggunakan metode kualitatif deskriptif. Hasil penelitian menunjukkan: (1) Implementasi Peraturan Daerah Kota Padang Nomor 5 Tahun 2018 tentang Pencegahan dan Peningkatan Kualitas Perumahan dan Permukiman Kumuh Kumuh di Kecamatan Koto Tangah belum berjalan dengan lancar. 2) Kendala yang ditemukan pemerintah dalam melaksanakan kebijakan ini adalah: (a) kurangnya kesadaran masyarakat dalam menjaga kualitas perumahan dan permukiman kumuh pemukiman di Kecamatan Koto Tangah. (b) keterbatasan sumber keuangan atau anggaran di Kabupaten Koto Tangah. (c) Kualitas sumber daya manusia yang terbatas. (3) Berdasarkan kendala yang dihadapi, upaya yang dilakukan oleh pemerintah adalah: (a) melakukan sosialisasi kepada masyarakat di Kecamatan Koto Tangah untuk meningkatkan kesadaran. (b) Menjalin kemitraan atau bekerjasama dengan UKM pembina UKM di kelurahan setempat, atau mengajukan proposal ke DPR yang berada di sekitar wilayah tersebut. (c) Membentuk Lembaga Pemasyarakatan (LPM) untuk memenuhi ketersediaan sumber daya manusia secara kuantitas.
\end{abstract}

Kata kunci: Implementasi kebijakan, Pencegahan, Peningkatan kualitas, Perumahan kumuh, Permukiman kumuh

\begin{abstract}
The prevention and improvement of the quality of slum areas is an important policy to prevent the growth and development of slum housing and slum settlements and to create a habitable and sustainable area. Even in Koto Tangah Subdistrict, housing and slum settlements continue to grow and develop, which was originally only covering an area of 11.5 ha and spread over 2 sub-districts then sprang up and developed new housing and slum settlements covering an area of 33.5 ha and spread across 4 villages in Koto District. Tangah. This research uses descriptive qualitative method.The results showed: (1) The implementation of the Padang City Regional Regulation Number 5 of 2018 concerning the Prevention and Improvement of the Quality of Housing and Slum Settlements in Koto Tangah District has not run smoothly. 2) The obstacles that the government found in implementing this policy were: (a) lack of public awareness in maintaining the quality of housing and slum settlements in Koto Tangah District. (b) limited financial resources or budget in Koto Tangah Regency. (c) Limited quality of human resources. (3) Based on the obstacles faced, the efforts made by the government are: (a) disseminating information to the community in Koto Tangah District to raise awareness. (b) Establishing partnerships or collaborating with UKM fostering UKM in the local kelurahan,or submitting proposals to the DPR in the vicinity of the area. (c) Establishing a Penitentiary (LPM) to meet the availability of human resources in quantity
\end{abstract}

Keywords: Implementation of policies, Prevention, Quality improvement, Slum housing, Slum settlements 


\section{Pendahuluan}

Perumahan dan permukiman merupakan sau kesatuan sistem yang terdiri dari pembinaan, penyelanggaraan kawasan perumahan dan permukiman, pemeliharaan serta perbaikan, pencegahan dan peningkatan kualitas perumahan dan permukiman kumuh (Walbertus, 2019:108). Pembangunan permukiman kota yang tidak berhasil, terkait erat dengan fenomena urbanisasi. Minimnya lahan di perkotaan dan ketidak tepatan rencana pembangunan perkotaan menjadi penyebab muncunya permukiman kumuh perkotaan. Sejalan dengan hal tersebut, Aminova dan Malau (2020:220) berpendapat bahwa salah satu alasan utama munculnya perumahan kumuh adalah harga rumah yang terus meningkat sehingga menyulitkan kelompok berpenghasilan rendah untuk mendapatkan perumahan yang layak. Karena kendala ekonomi masyarakat terpaksa tinggal diperumahan sementara. Kota Padang merupakan salah satu dari sedikit kawasan di Sumatera Barat yang tidak lepas dari permasalahan kawasan kumuh.

Menurut SK Walikota No 501/2019 trntang penetapan lokasi permukiman kumuh, luas kawasan kumuh di Kota Padang Sebagai berikut:

Tabel 1. Kawasan kumuh Kota Padang

\begin{tabular}{|c|c|c|c|c|}
\hline No & Kecamatan & Kelurahan & $\begin{array}{c}\text { Luas Kawasan } \\
\text { Kumuh (Ha) }\end{array}$ & $\begin{array}{c}\text { Rumah Tidak Layak } \\
\text { Huni (RTLH) }\end{array}$ \\
\hline \multirow[t]{4}{*}{1.} & \multirow[t]{4}{*}{ Koto Tangah } & Batipuh Panjang & 6,30 & 224 unit \\
\hline & & Batang Kabung Ganting & 4,55 & 77 unit \\
\hline & & Balai Gadang & 11,90 & 340 unit \\
\hline & & Padang sarai & 13,60 & 181 unit \\
\hline \multirow[t]{3}{*}{2.} & \multirow[t]{3}{*}{ Lubuk Begalung } & Koto Baru Nan Xx & 2,84 & 100 unit \\
\hline & & Banuaran & 6,03 & 137 unit \\
\hline & & Lubuk Begalung Nan xx & 2,58 & 35 unit \\
\hline \multirow[t]{3}{*}{3.} & \multirow[t]{3}{*}{ Bungus Teluk Kabung } & Teluk Kabung Selatan & 16,68 & 135 unit \\
\hline & & Bungus Barat & 10,66 & 144 unit \\
\hline & & Bungus Timur & 1,68 & 335 unit \\
\hline 4. & Nanggalo & Tabing Bandar Gandang & 3,00 & 27 unit \\
\hline \multirow[t]{2}{*}{5.} & \multirow[t]{2}{*}{ Kuranji } & Pasar Ambacang & 2,52 & 231 unit \\
\hline & & Anduring & 8,48 & 134 unit \\
\hline 6. & Padang Barat & Flamboyan Baru & 3,56 & 90 unit \\
\hline \multirow{4}{*}{\multicolumn{2}{|c|}{ Pauh }} & Pisang & 1,06 & 97 unit \\
\hline & & Limau Manis & 1,70 & 166 unit \\
\hline & & $\begin{array}{l}\text { Binuang Kampung } \\
\text { Dalam }\end{array}$ & 11,05 & 65 unit \\
\hline & & Piai Tangah & 5,28 & 32 unit \\
\hline \multirow{5}{*}{\multicolumn{2}{|c|}{ 8. Lubuk Kilangan }} & Bandar buat & 2,27 & 144 unit \\
\hline & & Tarantang & 2,83 & 45 unit \\
\hline & & Padang Besi & 2,36 & 60 unit \\
\hline & & Koto Lalang & 1,40 & 55 unit \\
\hline & & & 122,33 & 2.854 unit \\
\hline
\end{tabular}


Berdasarkan tabel 1 di atas, dapat diketahui Salah satu kawasan kumuh terletak di Kecamatan Koto Tangah Kota Padang. Perumahan dan permukiman kumuh tersebut tersebar di 4 kelurahan dengan luas 36,35 ha dan rumah tidak layak huni mencapai 822 unit rumah. Sebelumnya, berdasarkan SK Walikota Padang Nomor 163 Tahun 2014, di Kecamatan Koto Tangah hanya 11,5 ha dan terdapat 2 kelurahan yang terindikasi kumuh. Kawasan kumuh dikelola pemerintah, sehingga menjadi kawasan layak huni. Namun, pemerintah hanya berfokus pada perbaikan menjadi kawasan layak huni. Sementara itu, untuk mencegah tumbuh kembangnya kawasan kumuh baru belum terlaksana secara optimal. Secara umum permasalahan yang dihadapi adalah terbatasnya akses perumahan yang layak dan sehat, bangunan rumah yang belum memiliki fasilitas MCK, serta kualitas bangunan yang belum memenuhi standar. Permasalahan ini perlu perhatian pemerintah pusat dan daerah untuk mewujudkan kesejahteraan masyarakat. Salah satunya implementasi kebijakan pencegahan dan perbaikan kawasan kumuh. Kebijakan tersebut bertujuan untuk mencegah tumbuh kembanya kawasan kumuh baru, serta meningkatkan kualitas kawasan kumuh agar layak huni. Melalui pemantauan dan pengendalian kawasan kumuh, kerja sama dengan instansi dan pihak terkait, serta partisipasi masyarakat dan kearifan lokal, juga dimungkinkan untuk mencegah dan meningkatkan pembangunan kawasan kumuh yang tertuang dalam kebijakan pencegahan dan perbaikan kawasan kumuh.

Dunn (dalam Setyati, 2015:61) mendefenisikan kebijakan sebagai rangkaian pilihan bersama (termasuk keputusan tidak melaksankan tindakan) yang rumuskan oleh pejabat pemerintah atau lembaga yang berwenang di bidang tanggung jawab tertentu. Berdasarkan pemahaman ahli di atas, terlihat bahwa kebijakan merupakan upaya untuk mencapai suatu tujuan dan merupakan sarana untuk mengatasi masalah dengan cara tertentu dan dalam kurun waktu tertentu. Tahap implementasi merupakan tahap yang menentukan, karena pada tahap ini kebijakan bersentuhan langsung dengan masyarakat dan dianggap sebagai tujuan kebijakan publik ("Kinerja Implementasi Kebijakan Penanganan Perempuan Korban Kekerasan,” 2014). Perda Kota Padang Nomor 5 Tahun 2018 sudah terlaksana di Kota padang. Dapat dilihat dari pemerintah mampu meningkatkan kualitas kawasan kumuh yang terdapat dalam SK Nomor 163/2014 menjadi kawasan yang layak huni dan berkelanjutan. Namun disisi lain, peraturan ini belum sepenuhnya terlaksana, karena fenomena di lapangan dilihat bahwa tumbuh dan berkembangya kawasan kumuh baru di Kota Padang. Dalam peraturan ini dicantumkan bahwa, pemerintah daerah mencegh tumbuh dan berkembangya kawasan kumuh dilaksanakan melalui pengendalian dan pengawasa, juga melaksankan pemberdayaan terhadap masyrakat. Sedangkan untuk melaksanakan peningkatan kualitas terhadap kawasan kumuh pemerintah melaksankan dengan menetapkan lokasi kawasan kumuh, penanganan, dan terakhir penegelolaan.Sejalan dengan hal tersebut, salah satu upaya untuk mencegah pertumbuhan dan perkembangan kawasan kumuh baru dengan melaksanakan pemberdayaan masyarakat yang tertuang dalam kebijakan tersebut. Namun nyatanya, di Kecamatan Koto Tangah, hal ini tidak berjalan dan menyebabkan tumbuh kembangnya kawasan kumuh baru. Seperti yang terlihat pada gambar di bawah ini.

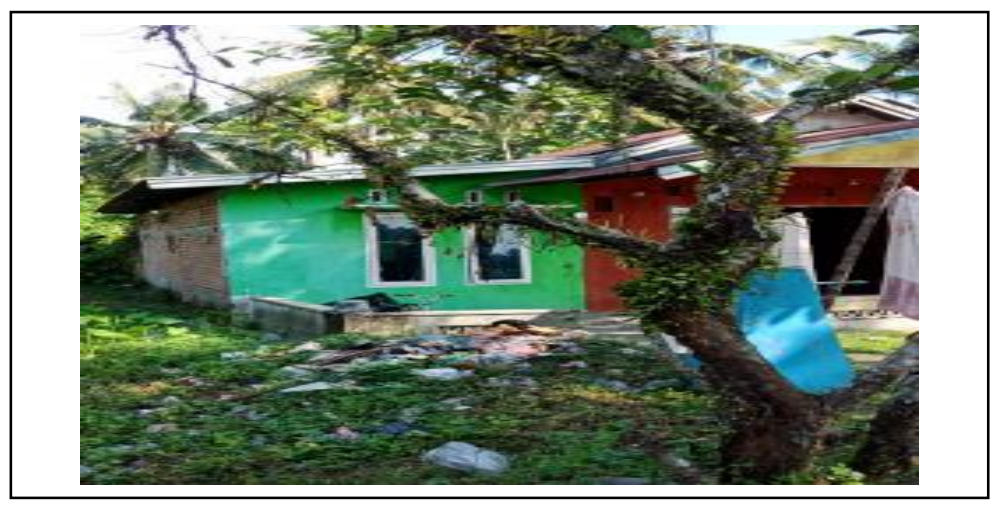

Gambar 1. Kawasan kumuh baru di Kecamatan Koto Tangah

Jurnal Perspektif: Jurnal Kajian Sosiologi dan Pendidikan Vol. 3, No. 4, Th. 2020 
Berdasar dari gambar 1.1 di atas dapat dilihat permukiman yang kumuh. Sampah menumpuk di depan rumah warga. Kawasan kumuh di atas merupakan kawasan kumuh baru di Kecamatan Koto Tangah. Perumahan dan permukiman kumuh tersebut tumbuh karena tidak ada upaya pencegahan dari pemerintah. Berkaitan dengan latar belakang permasalahan telah dipaparkan, maka penulis tertarik untuk meneliti dan mencermati permasalahan terkait pencegahan dan perbaikan kualitas kawasan kumuh. Berdasarkan hal tersebut, penulis mengangkat sebuah judul penelitian tentang, "Implementasi Peraturan Daerah Kota Padang Nomor 5 Tahun 2018 Tentang Pencegahan dan Peningkatan Kualitas perumahan Kumuh dan Permukiman Kumuh di Kecamatan Koto Tangah " Rumusan masalah dalam penelitian ini sebagai berikut:

1. Bagaimana implementasi kebijakan pencegahan dan perbaikan kawasan kumuh di Kecamatan Koto Tangah?

2. Apa saja kendala dalam implementasi implementasi kebijakan pencegahan dan perbaikan kawasan kumuh di Kecamatan Koto Tangah?

3. Upaya mengatasi kendala implementasi kebijakan pencegahan dan perbaikan kawasan kumuh di Kecamatan Koto Tangah?

\section{Metode Penelitian}

Penelitian ini menggunakan metode penelitian kualitatif dengan pendekatan deskriptif. Menurut Moelong (Lexi \& M.A., 2010) penelitian kualitatif merupakan proses penelitian yang mengahsilkan data deskriptif dan perilaku yang dapat diamati yang diekspresikan dalam bentuk tertulis atau verbal. Penelitian ini dilaksanakan di Dinas Perumahan Rakyat Kawasan Permukiman dan Pertanahan Kota Padang (DPRKPP) dan di kawasan kumuh di Kecamtan Koto Tangah Kota Padang. Informan dalam penelitian ini ditentukan secara purposiv sampling. Sebagaimana dikemukakan (Sugiyono, 2012) purposive sampling merupakan terknik pemilihan sumber data untuk pemilihan tertentu. Purposiv sampling digunakan dalam penelitian ini agar peneliti dapat memperoleh data yang valid dan maksimal. Teknik lain yang digunakan untuk menentukan informan adalah snowball sampling. Pengumpulan data dalam penelitian ini dilakukan melalui penggunaan pedoman wawancara, observasi (pengamatan) dan studi dokumentasi. Adapun informan dalam penelitian ini yaitu: (1) Kasi bangunan dan sarana pemerintahan DPRKPP, (2) Kasi Penyediaan perumahan dan pengembangan kawaan DPRKPP, (3) lurah-lurah di Kawasan kumuh Kecamatan Koto Tangah (4) masyarakat yang berdomisili di Kawasan kumuh Kecamatan Koto Tangah. Teknik analisis data yang digunakan dimulai dengan pengumpulan data, reduksi data, penyajian data dan grafik kesimpulan. Suatu teknik untuk menguji keabsahan data dengan menggunakan teknik triangulasi sumber.

\section{Hasil dan Pembahasan}

\section{Implementasi Perda Kota Padang Nomor 5 Tahun 2018 Tentang Pencegahan dan Perbaikan Kawasan Kumuh di Kecamatan Koto Tangah}

Implementasi kebijakan merupakan aspek penting dalam keberhasilan kebijakan. Implementasi dalam keijakan tidak hanya melibatkan pengambilan keputusan politik tentang masyarakat melalui prosedur yang telah ditetapkan, tetapi juga melibatkan isu-isu yaitu keputusan siapa mendapat apa dari kebijakan tersebut (Zulkarnain, 2017). Model implementasi yang dikemukakan oleh Van Metter dan Van Horn yang menunujukkan bahwa implementasi kebijakan dijalankan secara linear oleh pelaksana kebijakan dan kinerja kebijakan publik. Van Metter dan Van Horn menetapkan 6 variabel yang dianggap berpengaruh terhdap implementasi serta kinerja dari suatu kebijakan, antara lain:

\section{Standar, Sasaran dan Tujuan}

Realitanya di lapangan pelaksanaan kebijakan ini adalah pemerintah tidak dapat bertindak sebagai lembaga pelaksana untuk mencapai tujuan kebijakan tersebut. Tujuan mencegah tumbuh dan berkembangya perumhan dan permukiman kumuh baru belum tercapai maksimal. Seperti yang 
dijelaksan oleh Bapak Well of sebagai kasi bangunan dan sarana prasarana pemerintah di Dinas Perumahan Rakyat Kawasan Permukiman dan Pertanahan Kota Padang bahwa:

\begin{abstract}
"pelaksanaan pencegahan ini belum sepenuhnya terlaksana, karena kami lebih berpriortas terhadap peningkatan kualitas perumahan kumuh dan permukiman kumuh. Seperti di Kecamatan Koto Tangah itu perumahan dan permukiman kumuhnya yang berdasarkan SK walikota tahun 2014 tentang penetuan wilayah perumahan dan permukiman kumuh di Kecamatan Koto Tangah terdapat 2 wilayah yang diindikasi sebagai perumahan dan permukiman kumuh dan itu sudah berhasil ditingkatkan menjadi perumahan dan permukiman layak huni sedangkan pencegahan kami laksanakan misalnya seperti ada masayarakat yang mengurus izin bangunan, disitu kami menerapakan peraturan yang berlaku sebagai salah satu bentuk pencegahan (07 juli 2020)”
\end{abstract}

Hal ini disebabkan karena rencana pencegahan terhadap tumbuh kembangnya kawasan kumuh belum terlaksana secara optimal. Misalnya, pengawasan dan pengendalian sarana- prasarana persampahan, sarana prasarana drainase lingkunga terhdap perumaan dan permukiman non kumuh tidak terlaksana secara efektif. Akibat minimnya upaya preventif dari pemerintah, sesuai SK Walikota Padang Nomor 501/2019 tentang penentuan lokasi kumuh, telah muncul kawasan kumuh baru di Kecamatan Koto Tangah yang luasnya 36,35 ha dan tersebar di 4 Kelurahan.

Menurut teori Van Metter dan Van Horn, kinerja implementasi kebijakan dapat diukur dari skala pelaksanaan kebijakan dan keberhasilan tujuan kebijakan. mengukur kinerja implementsi kebijakan pasti menentukan standar, sasaran dan tujuan yang harus dicapai oleh pelaksana kebijakan. Jika pelaksana tidak sepenuhnya memahami standar dan tujuan kebijakan penerapan kebijakan yang berhasil dapat gagal. Berdasarkan hasil penelitian di lapangan dan teori yang digunakan dapat dilihat bahwa stndar, tujuan dan sasaran dari Perda Kota Padang Nomor 5 Tahun 2018 tentang Pencegahan dan peningkatan kualitas kawasan kumuh belum dapat dipahami oleh para pelaksana kebijakan. Sehingga tujuan yang telah ditetapkan dalam perda tersebut belum dapat diwujudkan secara keseluruhan. Buktinya kawasan kumuh baru terus tumbuh dan berkembang d Kecamtan Koto Tangah karena bentu pencegahan yang tidak maksimal.

\title{
Sumber Daya
}

Kekuatan suatu organisasi berantung pada kemampuannya menggunakan berbagai sumber daya untuk mencapai tujuan. Hasil penelitian di lapangan menunjukkan bahwa sumber daya yang dimiliki oleh Dinas Perumahan Rakyat,Kawasan Perumahan Kota Padang sebagai pelaksana kebijakan belum memadai untuk mencegah dan memperbaiki perumahan kumuh dan permukiman kumuh. Sumber daya manusia yang tersedia di Kecamatan Koto Tangah dalam pengembangan kebijakan juga belum memadai, sehingga dalam implementasi kebijakan, pemerintah lebih berprioritas pada peningkatan kualitas perumahan dan permukiman kumuh. Seperti yang dijelaskan oleh Bapak Virgistia sebagai Kasi kasi penyediaan perumahan dan pengembangan kawasan permukiman bahwa:

\begin{abstract}
"SDM di kantor ini saya rasa sudah sesuai dengan keahlinnya dan berusaha untuk menjalankan tugas sesuai dengan tugas pokok dan fungsinya masing-masing, namun dalam implementasi ini pengarahan sumber daya manusianya belum maksimal karena jumlahnya yang terbatas tidak sesuai dengan luas kawasan kumuh yang perlu penanganan dan masih menjadi salah satu kendala yang ditemui di lapangan (08 Juli 2020)"
\end{abstract}

Berdasarkan wawancara di atas dapat dilihat bahwa, jumlah sumber daya manusia yang dibutuhkan masih kurang untuk melaksnakan kebijakan karena jumlah sumber daya manusianya tidak sebanding dengan luas kawasan kumuh yang perlu penanganan. Menurut Donald Van Metter dan van Horn (dalam Fadlurrahman, 2014:172) sumber daya yang telah dimasukkan ke dalam rencana dan akan 
diubah menjadi keluaran atau produk dari rencana kebijakan. Sumber daya merupakan faktor penting untuk implementasi kebijakan efektif. Sedankan menurut Mulyadi (dalam Hasibuan,dkk, 2016:62) setiap kebijakan harus didukung oleh sumber daya yang memadai, baik sumber daya manusia maupun sumber daya keuangan. Hal ini terkait dengan sumber daya yang tersedia untuk mendukung keberhasilan implementasi sebuah kebijakan. Berdasarkan hasil penelitian di lapangan dan teori yang digunakan dapat disimpulkan bahwa sumber daya manusia dilihat dari segi kuantitas belum memadai dalam implementasi kebijakan perda tersebut. Sehingga pemerintah Kota Padang hanya berfokus pada peningkatan kualitas di Kecamatan Koto Tangah, sedangkan bentuk pencegahannya belum tampak jelas. Sehingga muncul kawasan kumuh baru di Kecamatan Koto Tangah.

\section{Komunikasi antar Organisasi}

Berdasarkan hasil penelitian di bidang ini, proses komunikasi antar organisasi atau pihak terkait dalam pelaksanaan pencegahan dan perbaikan kebijakan perumahan kumuh dan permukiman kumuh di Kecamatan Koto Tangah Kota Padang berada dalam kondisi baik. Dapat dilihat berdasarkann hasil penelitian dilapangan bahwa Dinas Perumahan Rakyat, Kawasan Permukiman Kota Padang melaksankan pertemuan antar organisasi terkait tugas dan pembagian tanggung jawab juga memberikan bukti komunikasi yang baik antar instansi terkait. Pada tingkat Kecamatan Koto Tangah juga mengadakan rapat koordinasi yang melibatkan seluruh kelurahan di Kecamatan Koto Tangah, yang membahas permasalahan yang di hadapi oleh kelurahan. Seperti yang dijelaskan oleh Bapak Yose Rizal sebagai Lurah Kelurahan Batang Kabung Ganting Kecamatan Koto Tangah bahwa:

\section{"Kami dari pihak kelurahan menjalin komunikasi dengan pihak kecamatan seperting mengadakan rapat koordinasi setiap hari senin untuk membahas permasalahan- permasalahan yang kami hadapi di kelurahan salah satunya ini perumuahan dan permukiman kumuh ini, kami selalu mengupayakan komunikasi yag maksimal, namun akhir-akhir ini kurang berjalan dengan lancar karena pandemi ini, apalagi saat PSBB berlaku kemaren (03 Juli 2020)"}

Berdasarkan pernyataan diatas dapat dilihat bahwa, pemerintah menjalin komunikasi dengan mengadakan rapat korrdinasi dalam membahas permasalahan yang dihadapi oleh kelurahan-kelurahan yang terindikasi sebagai wilayah kumuh di Kecamatan Koto Tangah. Van Horn dan Van Metter (dalam Akibu,2015:67-68) menjelaskan kebijakan publik dapat dimplementasikan secara efektif dan pelaksana individu harus memaahami apa tujuan standar itu. Komunikasi dalam rangka memberikan informasi kepada pelaksanaa kebijakan tentang apa yang menjaadi standar dan tujuan harus berasal dari konsistensi dan kesatuan berbagai sumber informasi. Berkaitan dengan hasil penelitian dibandingakn dengan teori yang digunakan dalam mengukur implementasi kebijakan, peneliti menyimpulkan bahwa komunikasi yang dijalin dalam implementasi kebijakan dapat dikatakan sudah baik pemerintah daerah Kecamtan Koto Tangah menjalin komunikasi dengan melaksanakan rpat koordinasi denga Lurah-Lurah di Kecamatan Koto Tangah.

\section{Karakteristik Agen Pelaksana}

Berdasarkan hasil penelitian yang telah dilaksanakan pelaksanaan tindakan preventif untuk mencegah dan meningkatkan kualitas kawasan kumuh di Kecamatan Koto Tangah belum memiliki standar yang dapat dijadikan acuan. Lembaga pelaksana dalam mengembangkan kebijakan di Kecamatan Koto Tangah memiliki latar belakang pendidikan yang berbeda-beda. Hal ini berbeda dengan karakteristik lembaga penegak kebijakan Dinas Perumahan Rakyat Kawasan Permukiman dan Pertanahan Kota Padang (DPRKPP) yang sumber daya manusianya memiliki latar belakang pendidikan sesuai dengan tugas dan fungsinya serta memiliki struktur organisasi yang baik. Oleh sebab itu masyarakat Kecamatan Koto Tangah tidak terlalu merasakan dampak dari kebijakan tersebut. 
Menurut Akibu (2015:4) fokus lembaga pelaksana meliputi organisasi informal dan formal yang terlibat dalam pelaksanaan kebijakan. Hal ini penting karena kinerja implementasi kebijakan akan sangat diepngaruhi oleh karakteristik yang tepat dan sesuai dengan instansi pelaksana. Menurut karakteristik organisasi Van Metter dan Van Horn organisasi sebagai pelaksana kebijakan harus demokratis dan meyakinkan. Demokrasi mengacu pada pelaksanaan kebijakan badan pelaksana sebagai wakil masyarakat dan badan pelaksana sebagai pelaksana kebijakan sesuai dengan tujuan, standar dan indikator yang ingin diapai. Sedangkan meyakinkan memiliki arti pelaksana hasru bisa mengajak dan mempengaruhi masyarakat. Berdasarkan hasil penelitian dan teori yang digunakan terlihat bahwa karakteristik DPRKPP sebagai pelaksana kebijakan dan implementor kebijakan di Kecmatan Koto Tangah memiliki karakteristik yang berbeda-beda. Terutama karakteristik pelaksana kebijakan di Kecamatan Koto Tangah yang bertindak sebagai pengembang perda di tingkat Kecamatan belum memiliki standar dan karakteristik yang baik. Karakteristik DPRKPP sebagai implementor kebijakan dan Karakteristik pemerintahan di Kecamatan Koto Tangah sebagai pengembang berbeda sehingga akan mempengaruhi lembaga pelaksana guna mencapai tujuan pencegahan dan peningkatan kualitas kawasan kumuh di Kecamatan Koto Tangah.

\section{Sikap Pelaksana (Disposisi)}

Implementor Perda Kota Padang nomor 5 Tahun 2018 bersikap menerima dan melaksanakan perda tersebut. Seperti yang dijelaskan oleh Bapak Well Of sebagai Kasi Bangunan, dan sarana prasana pemerintah bahwa:

"sikap kami menerima kebijakan ini, karena ini kami jadikan sebagai acuan dalam melaksankan peningkatan kualitas terhadap perumahan dan permukiman yang sudah diindikasi kumuh (07 Juli 2020)”

Berdasarkan wawancara diatas dapat dilihat bahwa pelsakana kebijakan dapat menerima dan melaksankan perda tentang pencegahan dan peningkatan kualitas kawasan kumuh. Di Kecamtan Koto Tangah juga telah dilaksanakan dan sudah dibenahi 2 kelurahan yang terindikasi sebagai kawasan kumuh.Van Metter dan Van Horn (dalam Akibu,2015: 67) meyakini bahwa sikap menolak atau menerima kebijakan akan sangat berhasil tidaknya implementasi kebijakan publik. Hal ini sangat dimungkinkan karena kebijakan yang dijalankan bukanlah hasil dari masyarakat lokal yang snagat paham dengan permasalahan yang dihadapi. Tetapi kebijakan publik bersifat top down yang pembuat keputusan tidak dapat memahami atau bahkan tidak dapat menyelesaikan kebutuhan, harapan atau masalah yang harus dibenahi. Berdasarkan hasil penelitian dan teori yang digunakan dapat dilihat bahwa, pelaksana Perda Kota Padang tersebut dapat menerima dan menjalankannya. Namun pelaksanaan di kecamatan Koto Tangah belum berjalan dengan baik karena DPRKPP hanya berfokus pada peningkatan kualitas kawasan kumuh di Kecamatan Koto Tangah. Sedangkan bentuk pencegahan tumbuh dan berkembangnya kawasan kumuh baru belum tampak jelas.

\section{Kondisi Lingkungan Sosial}

Kondisi lingkungan sosial terkait pelaksanaan kebijakan preventif dan peningkatan kualitas perumahan kumuh dan permukiman kumuh di Kecamatan Koto Tangah belum sepenuhnya mendukung. Berdasarkan data di lapangan ditemukan bahwa pertenantangan dari masyarkat Batang Kabung Ganting, yang tidak merelakan tanah untuk membangun saluran limbah masyarakat. Masih terdapat beberapa masyarakat yang menggunakan bantuan sebagai penghasilan. Misalnya masyarakat yang tinggal di rumah yang tidak layak huni diberikan bantuan secara tunai oleh pemerintah Kota Padang. Masyarakat sendiri yang memilih toko bangunan untuk membeli bahan-bahan yang diperlukan untuk renovasi rumah. Namun pada kenyataannya masih ada masyarakat di Kecamatan Koto Tangah yang menyalahgunakan bantuan tersebut. Masyarakat belum memahami bahwa pencegahan dan penigkatan 
kualitas kawasan kumuh dapat meningkatkan kesejahteraan sosial masyarakat. Lingkungan sosial untuk implementasi kebijakan merupakan lingkungan eksternal yang membantu pelaksanaan kebijakan preventif sampai batas tertentu dan melaksanakan pencegahan dan peningkatan kualitas kawasan kumuh di Kecamtan Koto Tangah. Lingkungan sosial yang tidak mendukung dapat mengakibatkan kegagalan implementasi begitu pula sebaliknya. Implementasi kebijakan membutuhkan kondisi lingkungan yang menguntungkan. Berdasarkan lingkungan sosial di Kecamatan Koto Tangah, dapat dilihat bahwa pencegahan dan perbaikan kawasan kumuh belum mencapai kondisi terbaik karena sikap masyarakat terhadap kebijakan.

\section{Kendala Implementasi Kebijakan Pecegahan dan Peningkatan Kualitas Kawasan Kumuh di Kecamatan Koto Tangah}

Menurut (Kamila dan Syamsir, 2019:276) dari pelaksanaan kebijakan dan desain kebijakan itu sendiri, konsistensi antara tujuan dan sasaran, serta pemberian hasil yang positif untuk menyelesaikan permasalahan yang dihadapi. Pada dasarnya pelaksanaan Peraturan daerah Kota Padang Nomor 5 Tahun 2018 terkait dengan pencegahan dan peningkatan kualitas perumahan kumuh dan permukima kumuh sedang berlangsung, namun proses pelaksanaannya tidak lepas dari kendala yang dihadapi. Berdasarkan uraian di atas hasil penelitian dibidang ini, peneliti menemukan bahwa pemerintah mengalami beberapa kendala dalam melaksanakan kebiajakn di Kecamatan Koto Tangah, yaitu:

Pertama, minimnya kesadaran masyarakat dalam mematuhi kebijakan tersebut, sehingga implementasi kebijakan pencegahan dan peningkatan kualitas kawasan kumuh di Kecamatan Koto Tangah belum berjalan dengan lancar. Selain itu kurangya dukungan dari masyarakt juga menjadi kendala pelaksanaan perda tersebut. Berdasarkan hasil penelitian yang dilakuka masyarakt di Kelurahan Batang Kabung Ganting Kecamatan Koto Tangah tidak memberikan tanah ulayatnya untuk dibangun saluran limbah masyarakat. Hal ini berpengaruh terhadap lancar tidaknya pelaksanaan pencegahan dan peningkatan kualitas kawasan kumuh di Kecmatan Koto Tangah.

Kedua, anggarannya terbatas, pemerintah menemukan kendala di bagian pembiayaan, karena dana yang dibutuhkan untuk pengelolaan kawasan kumuh tidak sebanding dengan luas perumahan dan permukiman yang sudah terindikasi kumuh. Terutama dana yang dibuthkan untuk kegiatan rencana pencegahan terhadap tumbuh dan berkembangnya kawasan kumuh baru di Kecamatan Koto Tangah. Pemerintah hanya berfokus pada peningkatan kualitas kawasan kumuh saja. Sehingga kawasan kumuh itu terus tumbuh dan berkembang di Kecamatan Koto Tangah.

Ketiga, sumber daya mausia tidak mencukupi untuk mendukung rencana kegiatan pencegahan dan perbaikan kualitas kawasan kumuh. Pasalnya, luas kawasan kumuh di Kecamatan Koto Tangah tidak bisa dibandingkan dengan sumber daya manusia disana. Terutama sumber daya manusia di Kecamatan Koto Tangah belum cukup dan memadai untuk melaksanakan kegiatan pencegahan dan peningkatan kualitas kawasan kumuh. Jumlah staf dan pegawai di setiap kelurahan di Kecamatan Koto Tangah hanya berjumlah sekitar 15 orang. Sedangkan untuk implementasi perda tersebut membutuhkan sumber daya manusia yang banyak. Karena sumber daya manusia di Kecamatan Koto Tangah tidak sebanding dengan luas kawasan kumuh di Kecamatan Koto Tangah.

Keempat, keadaan sosial, budaya dan ekonomi di Kecamatan Koto Tangah juga berpengaruh terhadap lancar atau tidaknya pelaksanaan kebijakan pencegahan dan perbaikan kualitas kawasan kumuh tersebut. Dari segi ekonomi, tingkat ekonomi masyarakat yang tinggal di kawasan yang terindikasi sebagai kawasan kumuh di Kecamatan Koto Tangah adalah menengah ke bawah. Hal ini bedampak pada kemampuan masyarakat menciptakan kawasan yang sehat dan layak huni. Faktanya dengan tingkat ekonomi menengah ke bawah, masyarakat belum mampu membangun perumahan yang baik dan layak huni. Sehingga perumahan kumuh dan tidak layak huni tetap berkembang di Kecamatan Koto Tangah. Karena masyarakat hanya mengaharpakan bantuan dari pemerintah setempat.

Kelima, kurangnya komitmen dan konsistensi pemerintah dalam menjalankan peraturan daerah tentang pencegahan dan perbaikan kualitas kawasan kumuh di Kecamatan Koto Tangah. Hal ini juga dipicu karena kurangnya pemahaman para implementor tentang tujuan dari kebijakan tersebut. 
Sehingga pemerintah dalam menjalankan kebijakan belum konsisten dan menyebabkan perumahan dan permukiman kumuh di Kecamatan Koto Tangah terus tumbuh dan berkembang.

\section{Upaya dalam Mengatasi Kendala Implementasi Kebijakan Pencegahan dan Perbaikan Kawasan Kumuh di Kecamatan Koto Tangah}

Upaya pemerintah untuk mengatasi kendala yang di hadapi dalam pelaksanaan perda tentang pencegahan dan perbaikan kualitas kawasan kumuh di Kecamatan Koto Tangah adalah sebagi berikut: pertama,infrastruktur tersebut berusaha menarik minat warga di Kecamatan Koto Tangah dengan mengakses langsung ke lapangan. Misalnya di Kelurahan Padang Sarai kelurahan menganjurkan kegiata warga bersama-sama membersihkan permukiman. Selain itu pemerintah juga memberikan layanan konsultasi kepada masyarakat tentang menjaga kebersihan hunian, dan menjaga kesehatan. Dengan dipancing infrastruktur pemerintah berharap tingkat kesadaran masyarakat di Kecamatan Koto Tangah semakin meninkat dengan begitu masyarakat dapat membantu jalannya kegiatan pencegahan dan perbaikan kualitas kawasan kumuh di Kecamatan Koto Tangah.

Kedua, Kelurahan di Kecamatan Koto Tangah berupaya mendapatkan dana dengan mengundang mitra yang berdomisili di kelurahan tersebut seperti UKM yang berkembang di Kecamatan Koto Tangah untuk membantu pendanaan. Selain itu tingkat kelurahan jugaa memninta bantuan kepada Dewan Perwakilan Rakyat (DPR) untuk membantu pendanaan.

Ketiga, Pemerintah meningkatan kualitas dan kuantitas sumber daya manusia dalam proses pencegahan dan perbaikan kualitas kawasan kumuh di Kecamatan Koto Tangah dengan membentuk lembaga pemasyarakatan di kelurahan yang membantu dalam menangani permasalahan yang dihadapi. Setiap kelurahan di Kecamatan Koto Tangah memiliki lembaga masyarakat yang membantu dalam melaksanakan tugas termasuk perbaikan kualitas kawasan kumuh. Sedangkan perbaikan dari segi kualitas, pemerintah Kota Padang memberikan sanksi infrastruktur bagi pelaksanan kebijakan yang tidak menjalankan tugas dan fungsinya dengan baik. Sehingga menimbulkan efek jera bagi implementor dengan begitu pemerintah sebagai pelaksana kebijakan pencegahan dan perbaikan kualitas kawasan kumuh di Kota Padang akan berupaya menjalankan tugas dengan baik dan benar, serta meningkatkan disiplin.

Keempat, melaksanakan pemberdayaan kepada masyarkat di Kecamatan Koto Tangah yang minim pengetahuan dan memiliki sifat tertutup. Seperti Pemerintah Kota Padang juga telah melaksankan pemberdayan masyarakat dengan pelatihan menjahit di Kecamatan Koto Tangah. Masyarakat yang ikut pelatihan tersebut diberikan mesin jahit oleh pemerintah. Hal ini bertujuan agar masyarakat di Kecamatan Koto Tangah dapat mengembangkan kemampuan dan mampu menciptakan pekerjaan sendiri untuk meningkatkan perekonomian dan taraf hidup masyarakat setempat. Selain itu pemberdayaan yang dilakukan tehdapa masyarakat yang berdomisili di kawasan kumuh Kecamatan Koto Tangah juga bertujuan untuk membukan pola pikir masyarakat sehingga mau terbuka pada pemerintah mengenai masalah permukiman yang dihadapi dan dicarikan solusinya dari pemerintah.

Kelima, meningkatkan pemahaman terhadap tujuan utama yang ingin dicapai dari peraturan daerah tentang pencegahan dan peningkatan kualitas perumahan kumuh dan permukiman kumuh ini. Membentuk kelompok kerja (POKJA) untuk mengatasi masalah perumahan dan permukiman kumuh. Melalui hal tersebut pemerintah dapat meningkatkan konsistensi dalam melakukan upaya pencegahan dan peningkatan kualitas perumahan dan permukiman kumuh di Kecamatan Koto Tangah.

\section{Kesimpulan}

Berdasarkan penjelasan di atas, dapat disimpulkan bahwa implementasi kebijakan pencegahan dan perbaikan kulitas kawasan kumuh di Kecamatan Koto Tangah berdasarkan hasil penelitian di lapangan dan dibandingkan dengan aspek toeritis yang digunakan. Peneliti menyimpulkan bahwa implementasi Perda Kota Padang Nomor 5 Tahun 2018 belum berjalan dengan baik. Hal ini dapat dilihat karena belum tercapainya semua tujuan yang telah ditetapkan dalam Perda tersebut. 
Pelaksanaannya dilapangan menunjukkan bahwa DPRKPP Kota Padang lebih berfokus pada perbaikan kualitas terhadap kawasan kumuh di Kecamatan Koto Tangah. Sedangkan bentuk pencegahan belum tampak jelas, sehingga kawasan kumuh baru terus tumbuh dan berkembang di Kecamatan Koto Tangah. Terdapat kendala yang di hadapi dalam proses pelaksanaan kebijakan, walaupun kebijakan sudah berjalan dengan baik, diantaraya yaitu:(a) tingkat kesadaran masyarakat yang minim. (b) keterbatasan sumber dana. (c) sumber daya manusia yang tersedia tidak memadai atau belum cukup dari segi kuantitas.(d) keadaan sosial ekonomi dan budaya masayrakat yang tinggal di kawasan kumuh Kecamatan Koto Tangah belum emndukung sepenuhya untuk pelaksanaan pencegahan dan perbaikan kualitas kawasan kumuh di Kecamatan Koto Tangah. (e) belum adanya konsistensi dari pemerintah Kota Padang untuk menjalankan perda pencegahan dan perbaikan kualitas kawasan kumuh di Kecamatan Koto Tangah

Upaya untuk mengatasi kendala yang dihadapi dalam implementasi kebijakan pencegahan dan perbaikan kawasan kumuh di Kecamatan Koto tangah yaitu: (a) sosialisasi kepada masyarak sebagai usaha untuk memancing minat warga, dan meningkatkan kesadaran masyarakat Koto Tangah. (b) menjalin mitra dengan UKM yang berkembag di Kecamatan Koto Tangah serta mengajukan proposal bantuan dana ke Dewan Perwakilan Rakyat (DPR). (c) membentuk Lembaga Pemasyarakatn di Kelurahan untuk membantu mencukupi sumber daya manusia. (d) melaksankan pemberdayaan terhadap masyarakat yang berdomisili di kawasan yang sudah terindikasi sebaga kawasan kumuh di Kecamatan Koto Tangah. (e) pemerintah membentuk POKJA dalam memingkatkan konsistensi dan pelaksanaan pencegahan dan perbaikan kualitas kawasan kumuh di Kecamatan Koto Tangah.

\section{Daftar Pustaka}

Akibu,R.(2015).Implementasi Kebijakan Perizinan Penyiaran TV Lokal di Provinsi Gorontalo.Jurnal Ilmu Administrasi Publik. Volume 4 No.2.

Aminova, Y, dan Hasbullah, M. (2020).Implementasi Program Kredit Perumahan Rakyat (KPR) bersubsidi bagi masyarakat berpenghasilan rendah di Kota Padang. Volume 3(1)

Indiahono,Dwiyanti.(2014). Kebijakan publik berbasis dinamic policy analisis.Gorontalo:UNG Pres Gorontalo

Kamila dan Syamsir (2019). Pelaksanaan program bantuan rumah tidak layak huni (RTLH) di Kelurahan Aie Pacah. Volume 1(2)

Kinerja Implementasi Kebijakan Penanganan Perempuan Korban Kekerasan. (2014). JKAP (Jurnal Kebijakan Dan Administrasi Publik). https://doi.org/10.22146/jkap.7520

Lexi, J., \& M.A., M. (2010). Metodologi Penelitian Kualitatif. In Metodologi Penelitian Kualitatif. Rake Sarasin.

Sugiyono. (2012). Metode Penelitian Kuantitatif, Kualitatif dan R \& D.Bandung:Alfabeta. Metode Penelitian Kuantitatif, Kualitatif Dan $R$ \& D.Bandung:Alfabeta. https://doi.org/10.1017/CBO9781107415324.004

Walbertus Maliano Lado Hikon,(2019). Strategi pemberdayaan masyarakat dalam mengubah permukiman kumuh menjadi destinasi wisata.vol 8 (13)

Zulkarnain, U. (2017). Analisis kebijakan standar pelayanan minimal untuk peningkatan kualitas layanan publik daerah. Jurnal Analisis Dan Kebijakan Publik.

Setyati.(2015).Implementasi Kebijakan Penataan Ruang Trebuka Hijau Kawasan Perumahan Kota Banjarbaru.Vol 9.No.1

Hasibuan,H,dkk.(2016).Implementasi Kebijakan Standar Kualifikasi dan Kompetensi Kepala SMk Negeri di Kabupaten Aceh.

Peraturan Daerah Kota Padang Nomor 5 Tahun 2018 Tentang Pencegahan dan Peningkatan Kualitas Terhadap Perumahan Kumuh dan Permukiman Kumuh

SK Walikota Padang Nomor 163/2014 Tentang Penetapan Kawasan Kumuh di Kota Padang SK Walikota Padang Nomor 501/2019 Tantang Penetapan Kawasan Kumuh di Kota Padang 